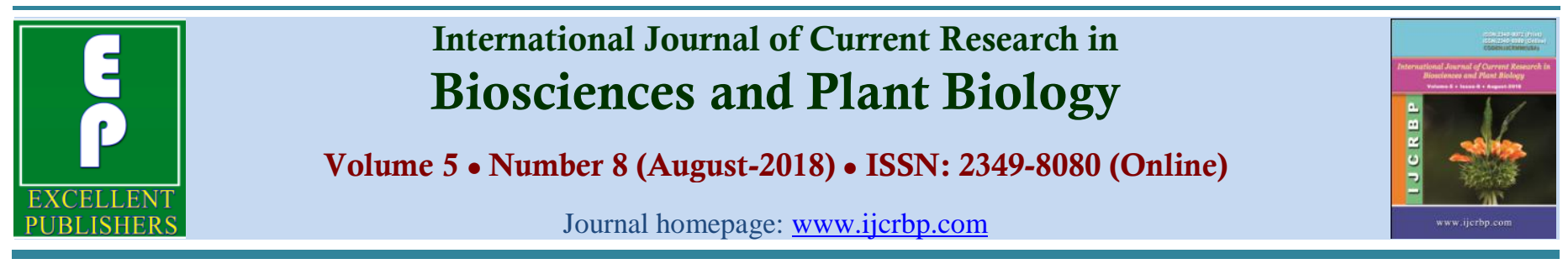

\title{
Evaluation of the Controlled Felling and Estimation of the Areas Impacted by the Timber Harvesting Operation at the Ngoua II Forest Exploitation Unit (UFE) in Southern Congo
}

\section{Pierre Mbete1, 2*, Leckoudnzou Ayessa ${ }^{1,2}$ and Clement Sosthène Oko, 2}

\author{
${ }^{1}$ Ecole Nationale Supérieure d'Agronomie et de Foresterie (ENSAF), République du Congo \\ 2Laboratoire de Géomatique et Ecologie Tropicale Appliquée, Université Marien N'gouabi (UMNG), \\ BP. 69, Brazzaville, République du Congo \\ ${ }^{*}$ Corresponding author.
}

\begin{tabular}{|c|c|}
\hline Article Info & \multirow{5}{*}{$\begin{array}{l}\text { The Ngoua II Forest Exploitation Unit is located in southern Congo and more } \\
\text { specifically in the chaillu massif. Controlled logging in Congolese forests is nowadays } \\
\text { an administrative obligation because of forest management in order to manage them } \\
\text { rationally and sustainably in the Republic of Congo. In our case Sapelli was found to be } \\
5596 \text { feet, and Mukulungu at } 1317 \text { feet, the other species had low proportions. The } \\
\text { actual production of the annual felling was centered on } 10 \text { species, but two species } \\
\text { were not felled of which: Acajou and Ayous. The projected volume of } 148732.48 \mathrm{~m}^{3} \text { and } \\
\text { at the end of the felling it was realized a net volume of } 17597.61 \mathrm{~m}^{3} \text { is a difference of } \\
131134.87 \mathrm{~m}^{3} \text {. To achieve this volume, four (4) logging companies were monitored and } \\
\text { the result of the controlled felling showed that on five felling operations, only the } \\
\text { safety cut was achieved (100\%) under good conditions, followed by the operation of } \\
\text { the cutting line ( } 99 \%) \text { and sapwood cutting ( } 97 \%) \text {, finally the wood hinge (61\%) and the } \\
\text { directional notch ( } 63 \%) \text { had acceptable proportions. An average surface area per foot } \\
\text { damage of } 863.31 \mathrm{~m}^{2} \text { was observed. Distribution of the area impacted by species during } \\
\text { the felling of trees and the shortening of forest roads to give an average surface area of } \\
9849.69 \mathrm{~m}^{2} \text {. Efforts must be made by the companies of the place to reduce the defects of } \\
\text { the tree felling in order to increase the material yield of the companies in the Congo. }\end{array}$} \\
\hline & \\
\hline & \\
\hline Keywords & \\
\hline $\begin{array}{l}\text { Forest cover } \\
\text { Safety cutting } \\
\text { Timber damage } \\
\text { Tree felling }\end{array}$ & \\
\hline
\end{tabular}

\section{Introduction}

The Republic of Congo covering a total area of $342000 \mathrm{~km}^{2}$, is located in the center of Africa, and straddles the equator, between latitudes $3 \circ 34$
North and $5^{\circ} 1$ 'South between longitudes $12^{\circ} 15^{\prime}$ East and $18^{\circ} 43$ 'West. The Congolese forest estate covers 22.47 million hectares, or $1 / 10$ of the dense forests of Central Africa. In terms of percentage, this area is estimated around $65 \%$ of the national 
territory of which 7million are in the flood zones, and the rest on firm ground (Mbete, 2014).

There are three major forest areas that make up this space, namely:

- The Mayombe Massif, on the Atlantic coast in the south of the country, covers $1,503,172$ ha, the main species being Limba and Okoumé (Terminalia superba), (Aucoumera klaineana);

- The chaillu massif, also located in the south, covers an area of 4,386,633.ha; these two massifs constitute the preferred zone of Limba (Terminalia superba) and Okoumé (Aucoumea klaineana), absent throughout the country;

- The forests of the North, by far the largest by its area: 15,991,604 ha, is the forest future of the Congo, including its timber resources, it is the area of Meliaceae, Sapelli (Etadrophragma cylindricum ) and Sipo (Miletia laurentii). It is also only in this massif that we find Ayous (Triplochiton scleroxylon) and Afromosia (Pericopis elata) (Boundzanga, 2005).

The wood whose wood potential value was estimated at 90 million cubic in the early 70s, was the first wealth of the country. But since then, it has been supplanted by oil, today accounting for less than $10 \%$ of state revenue, contributing only about 3 to $4 \%$ of GDP. However, beyond its place in the economy, which remains important, the forestry sector provides a significant share of the employment of around 10,000 permanent jobs (IUCN, 1991).

Almost all of the southern massifs (Mayombe and Chaillu) had been exploited for several times for more than 50 years, with the exception of a few remote areas. Timber cutting was selective for commercially valuable species such as Okoumé and Limba. This area is now impoverished because of these two species, but also by repeated passages by shifting cultivation on slash-and-burn. In the north for example, the exploitation is relatively recent, it began only about thirty years, with only one passage in very selective exploitation dominated by Sapelli (58\% of the national production). Unlike the southern zone, the northern zone has benefited from the beginning of its development of a simplified management regime, the extraction taking place every year in an area and leaving the exploited areas in a fallow situation.

Due to the remoteness of the area and the evacuation ports, and the resulting high production costs, the valuation mainly concerns four (04) species: Sapelli, Sipo Wengué (Milecia laurentii) and the light Bossé (Guarea cedrata), the other essences represent only small volumes. Logging in the northern zone shows that about $75 \%$ of the area alone is 10 million hectares exploitable and has been awarded as a concession to forestry companies.

Currently, a new forest policy has been adopted by the Congolese government with the definition of a legal framework appropriate by law 16-2000 of 20 November 2000 on the forest code which specifies the principles of management, conservation and use of ecosystems. on the basis of rational management of resources for sustainable development in order to fulfill certain relevant ecological, economic and social functions (Mbete, 2014).

Indeed, the new Forest Code requires the development of management plans in all forest concessions, an essential tool for the sustainable management of forests so that they sustainably fulfill.

The implementation of reduced impact logging (RIL) methods by some companies in Congo has the effect of minimizing (negative) impacts on the environment through the reduction of biomass, damage to the residual stand, habitat fragmentation, seed loss and others.

The general objective of this work was to estimate the actual and projected volumes of timber retained in the exploitation inventories and to identify certain practices on the technique of controlled culling. 
To achieve this study, the specific objectives considered were:

$\checkmark$ Know the projected workforce of the annual cut targeted by the company;

$\checkmark$ Evaluate log production in relation to their destination (sawmill, export) according to the objectives of the company;

$\checkmark$ Evaluate the implementation rate of the stages of feller-controlled feller;

$\checkmark$ Evaluate the results of the controlled felling technique on vegetation during logging and forest road lighting.

\section{Materials and methods}

\section{Materials}

For the collection of field data, the following equipment was used:

- A prospecting map

- A machete
- A camera

- Double decameter

- Excel software and a laptop.

\section{Methods}

For the evaluation of logging production, we used tree measurements from the felling lines to the second section (crown height). Slaughter is the operation that comes after tracking. Controlled felling was applied, with the following objectives:

- Maximize the safety of the feller team;

- Achieve a higher recovery rate (remove the foothills, avoid a better feller breakages and slips);

- Decrease as much as possible the damage to the remaining stand (IFO, 2007).

To cut down one foot of a gasoline tracked by the tracking team, the feller must follow the following steps in the field to be in compliance with the rules of EFIR (Fig. 1).

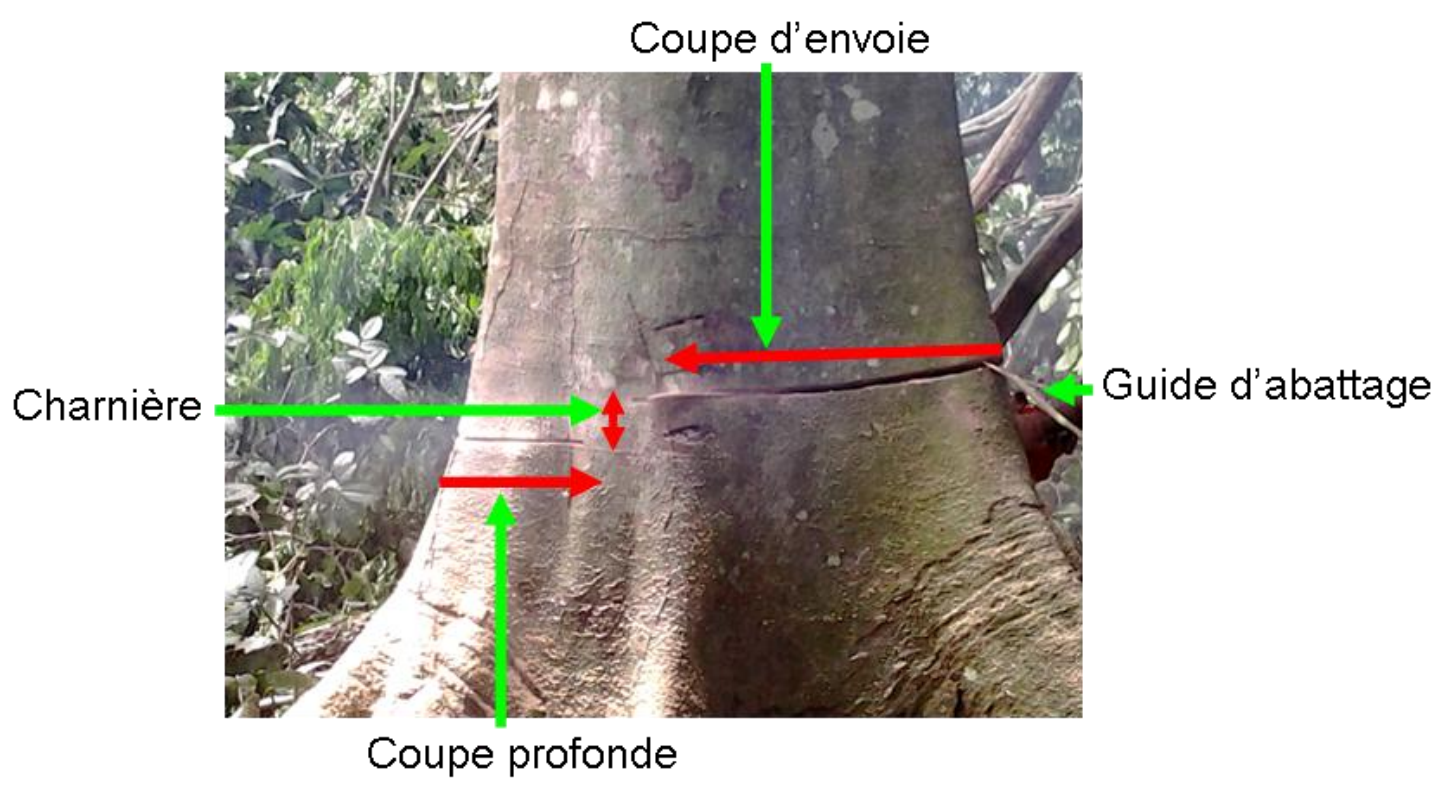

Fig. 1: Cutting of Sapelli at base.

To observe the EFIR rules, it necessarily goes through the following steps:

1. Look at the tension of the tree, in order to appreciate the direction of fall of the tree;
2. Make the escape route: the diagonal direction or $45^{\circ}$ relative to the direction of fall, the length is between 10 and $15 \mathrm{~m}$, the track quality well cleaned by cutting the vegetation;

3. Look at the height of cut: in relation to the 
ground (as low as possible), do egobing if necessary (for trees with buttresses) with sufficiently pronounced angle;

4. Make the directional cut of the tree (for trees without buttresses):

$\checkmark$ If the tree at a straight (normal) position, the notch must reach the east;

$\checkmark$ If the tree is tilted, the leaner the tree, the smaller the notch;

$\checkmark$ A good notch is determined by the length of the hinge.

5. Prepared the hinge, it is always made of "V" shaped crocodile jaws at the center of the stump with a shoulder height and the thickness should have about four (4) fingers and the length of the hinge should be between 30 and $50 \mathrm{~cm}$ (about 1.5 to 2 gloves);

6. Make the felling cut, the feller must make a shoulder, the height between felling cut and notch must have at least 4 fingers, line / horizontal line, sometimes takeoffs are necessary, no tearing in the perfect wood, everything is cut + piercing at heart in the notch if need (Ex: large diameter);

7. Sapwood cut or Mustaches: here the cutter must cut both sides of the hinge;

8. Mortise cut: the feller must do it before the final cut, at least one mortise per foot in the buttress;

9. Final cut: the security size must be small enough (IFO, 2013).

The stump of one foot of a shot-down gasoline (Fig. 2 ) is subject to the application of standards and principles of "controlled feller".

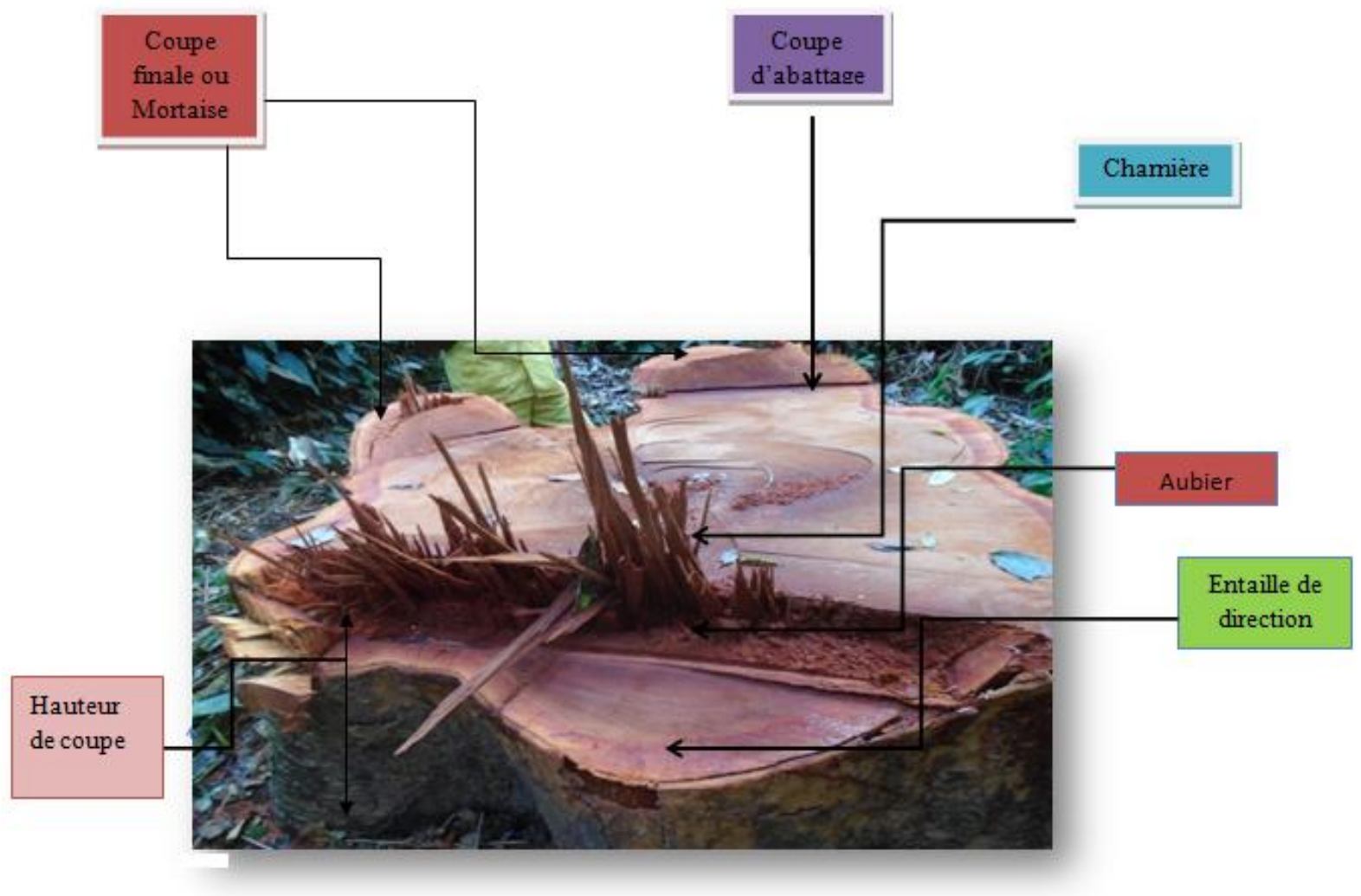

Fig. 2: Principles of "Controlled felling" on the stump of Sapelli's base.

Tree felling must be in accordance with the controlled feller rules established. Where possible and without jeopardizing their safety, fellers should seek to avoid future trees near the tree to be felled. The feller must avoid falling trees into the bed of a watercourse or swamp. Safety rules must be respected (eg.: wearing helmets and gloves, prohibiting the presence of other people than the nearby feller team, etc.) (IFO, 2007). The role of the feller is:

1. Follow the tracking tracks;

2. Cut down the tracked trees, following the 
indicators and the map;

3. Avoid abandonment unjustified;

4. Respect the standards of "controlled felling";

5. Hammer the stumps and take the lengths;

6. Post numbers on the map

The criteria for assessing checkpoints were:

$\checkmark$ Presence of the notch of direction: absence 1points; presence 0 point;

$\checkmark$ Saw cut (safety): absence 1, presence 0

$\checkmark$ Presence of the escape route: absence 1; presence 0

$\checkmark$ Cutting line (mustache or sapwood cut): absence, 0 presence 1

Evaluation of the fall direction by the faller: with respect to the axis of the directional cut, the tree fell in a $90^{\circ}$ angle, it was noted 0 ; and the fallen tree at an angle of $120^{\circ}$, the number 1 was noted. Slaughtering is the set of working techniques used to cut a standing tree. Nowadays, with the new policy focused on the sustainable management of forest ecosystems, controlled logging is practiced, which makes it possible, among other things, to avoid damage to the remaining stand. Faced with this new challenge, we measured the width and length of windthrow after felling each tree. All felled trees encountered were identified botanically and five measures are shown in Fig. 3.

These measurements in meters are:

- diameter at the base of the drum or big end diameter, determined by cutting (bucking) at the abutment;

- diameter at the top of the barrel or small end diameter $(\mathrm{m})$, determined by cutting at the head;

- length of the barrel, determined by these cuts and corresponds to the ball skate;

- length of the crown, determined by cutting at the head to the top;

- width of the crown.

The diameter at the base and at the top were measured using a $7.5 \mathrm{~m}$ graduated tape, while the length of the bole, the length and the width of the crown were measured using a double decameter.

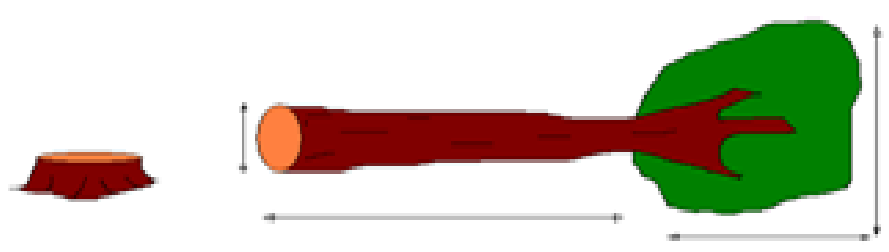

Fig. 3: Diagram illustrating taking measurements for a felled tree (Mbete, 2014).

The volume of the $\log (\mathrm{m} 3)$ and the area occupied by each felled tree were also calculated. To have the degraded surfaces of felled trees, it was necessary to calculate the lengths and widths of its surfaces in order to determine the polygon in square meters.

\section{Results}

According to the company's approach, we found that the company had several orders in the Sapelli species with 5596 feet, and the Mukulungu with 1317 feet, the other species had low proportions and Table 1 summarizes the forecast production.

Table 1. Number of projected production of the annual cut.

\begin{tabular}{llll}
\hline Species & $\begin{array}{l}\text { Number of } \\
\text { feet cut } / \\
\text { year }\end{array}$ & $\begin{array}{l}\text { Average } \\
\text { volume } / \\
\text { Feet }\left(\mathbf{m}^{\mathbf{3}}\right)\end{array}$ & $\begin{array}{l}\text { Total } \\
\text { projected } \\
\text { volume } \\
\left(\mathbf{m}^{\mathbf{3}}\right)\end{array}$ \\
\hline Acajou & 12 & 15 & 178.47 \\
Ayous & 214 & 19.5 & 4164.51 \\
Bossé & 186 & 12 & 2230.98 \\
Dossier & 54 & 12.5 & 669.29 \\
Iroko & 109 & 13 & 1412.95 \\
Mukulungu & 1317 & 19 & 25031.68 \\
Pau rosa & 134 & 10 & 1338.59 \\
Sapelli & 5596 & 18 & 100736.54 \\
Sipo & 334 & 21 & 7020.17 \\
Tali & 626 & 9.5 & 5949.3 \\
Total & $\mathbf{8 5 8 2}$ & & $\mathbf{1 4 8 7 3 2 . 4 8}$ \\
\hline
\end{tabular}

Compared to the forecast production, the actual production of this annual cut that we have followed is as follows: out of the 10 species planned by the company, we found that two species were not felled it is a question of Acajou and Ayous. The estimated volume of 148732.48 
$\mathrm{m}^{3}$ at the end of the feller it was realized a net volume of $17597.61 \mathrm{~m}^{3}$ is a difference of $131134.87 \mathrm{~m}^{3}$. According to the company's guidelines, we found that Sapelli species volume $867.441 \mathrm{~m}^{3}$ and Mukulungu $518.760 \mathrm{~m}^{3}$ were more for export than sawmill (Table 2).

Table 2. Distribution of log production by species, volume and destination of logs.

\begin{tabular}{|c|c|c|c|c|c|}
\hline \multirow[t]{2}{*}{ Species } & \multicolumn{2}{|c|}{ Number of balls } & \multicolumn{2}{|c|}{ Volume $\left(\mathrm{m}^{3}\right)$} & \multirow{2}{*}{$\begin{array}{l}\text { Volume total } \\
\left(\mathbf{m}^{3}\right)\end{array}$} \\
\hline & Export & Sawmill & Export & Sawmill & \\
\hline Acajou & 0 & 0 & 0,000 & 0,000 & 0,000 \\
\hline Ayous & 0 & 0 & 0,000 & 0,000 & 0,000 \\
\hline Bossé & 12 & 19 & 63,963 & 60,596 & 124,559 \\
\hline Dossier & 2 & 1 & 11,476 & 2,799 & 14,275 \\
\hline Iroko & 0 & 2 & 0,000 & 5,379 & 5,379 \\
\hline Mukulungu & 60 & 43 & 518,760 & 223,022 & 741,782 \\
\hline Pau rosa & 16 & 3 & 62,094 & 8,306 & 70,400 \\
\hline Sapelli & 116 & 440 & 867,441 & 2545,801 & 3413,242 \\
\hline Sipo & 18 & 29 & 162,021 & 227,000 & 389,021 \\
\hline Tali & 22 & 19 & 126,040 & 52623 & 178,663 \\
\hline Total & 246 & 556 & 1811,795 & 3125,526 & 49337,321 \\
\hline
\end{tabular}

To evaluate the rate of execution of the stages of the controlled feller, the follow-up of four (04) teams of slaughterers according to the errors per operation or stages of the feller compared to the points and percentage affected by team gives us Table 3.

Table 3. Execution rate of stages of cutting -controlled felling.

\begin{tabular}{|c|c|c|c|c|c|c|c|c|c|c|c|}
\hline \multirow{2}{*}{$\begin{array}{l}\text { Code } \\
\text { of the } \\
\text { Feller }\end{array}$} & \multirow{2}{*}{$\begin{array}{l}\text { Steps to } \\
\text { execute } \\
\text { Exécution }\end{array}$} & \multicolumn{2}{|c|}{ Nick direction } & \multicolumn{2}{|l|}{ hinge } & \multicolumn{2}{|l|}{ Cut line } & \multicolumn{2}{|c|}{ Cutting sapwood } & \multicolumn{2}{|l|}{ Safeness } \\
\hline & & $\begin{array}{l}\text { Well } \\
\text { executed }\end{array}$ & $\begin{array}{l}\text { Badly } \\
\text { executed }\end{array}$ & $\begin{array}{l}\text { Well } \\
\text { executed }\end{array}$ & $\begin{array}{l}\text { Badly } \\
\text { executed }\end{array}$ & $\begin{array}{l}\text { Well } \\
\text { executed }\end{array}$ & $\begin{array}{l}\text { Badly } \\
\text { executed }\end{array}$ & $\begin{array}{l}\text { Well } \\
\text { executed }\end{array}$ & $\begin{array}{l}\text { Badly } \\
\text { executed }\end{array}$ & $\begin{array}{l}\text { Well } \\
\text { executed }\end{array}$ & $\begin{array}{l}\text { Badly } \\
\text { executed }\end{array}$ \\
\hline \multirow[t]{2}{*}{ A1 } & Effective & 9 & 16 & 12 & 13 & 25 & 0 & 25 & 0 & 25 & 0 \\
\hline & Percentage & $36 \%$ & $64 \%$ & $48 \%$ & $52 \%$ & $100 \%$ & $0 \%$ & $100 \%$ & $0 \%$ & $100 \%$ & $0 \%$ \\
\hline \multirow[t]{2}{*}{ A2 } & Effective & 21 & 4 & 24 & 1 & 25 & 0 & 25 & 0 & 25 & 0 \\
\hline & Percentage & $84 \%$ & $16 \%$ & $96 \%$ & $4 \%$ & $100 \%$ & $\%$ & $100 \%$ & $0 \%$ & $100 \%$ & $0 \%$ \\
\hline \multirow[t]{2}{*}{ A3 } & Effective & 17 & 8 & 9 & 16 & 24 & 1 & 23 & 2 & 25 & 0 \\
\hline & Percentage & $68 \%$ & $32 \%$ & $36 \%$ & $64 \%$ & $96 \%$ & $4 \%$ & $92 \%$ & $8 \%$ & $100 \%$ & $0 \%$ \\
\hline \multirow[t]{2}{*}{ A4 } & Effective & 16 & 9 & 16 & 9 & 25 & 0 & 24 & 1 & 25 & 0 \\
\hline & Percentage & $64 \%$ & $36 \%$ & $64 \%$ & $36 \%$ & $100 \%$ & $0 \%$ & $96 \%$ & $4 \%$ & $100 \%$ & $\%$ \\
\hline \multicolumn{2}{|c|}{ Grand total } & 63 & 37 & 61 & 39 & 99 & 1 & 97 & 3 & 100 & 0 \\
\hline
\end{tabular}

It can be seen that the execution of different stages of controlled felling in Table 4 shows that all the steps are executed. For the evaluation of the rate of execution, it reveals that the cutting line, the cut of the sapwood and the security are the best applied, compared to the notch of direction and the hinge of wood remains. Of these four fellers that we followed during the study, we can note that only the A2 feller trying to perform better in all stages of controlled felling followed 
by the A4 feller. It can be seen that the directional notch and the wooden hinge presented serious difficulties of execution. The quantification and analysis of the damage of the feller (area impacted) according to the harvesting by the logging of the number of stems and volume taken gives us the Table 4. The comparison of the degraded area due to logging to the area of unharvested species indicates that the area degraded during our study relative to the remaining area of the annual harvest as shown in Table 5.

Table 4. Evaluation of the area of vegetation impacted during the controlled felling of the seven (7) species.

\begin{tabular}{llllllll}
\hline Species & $\begin{array}{l}\text { Number of } \\
\text { feet felled }\end{array}$ & $\begin{array}{l}\text { Total } \\
\text { volume } \\
(\mathbf{m 3})\end{array}$ & $\begin{array}{l}\text { Length of } \\
\text { the tree }(\mathbf{m})\end{array}$ & $\begin{array}{l}\text { Total length } \\
\text { of the tree } \\
(\mathbf{m})\end{array}$ & $\begin{array}{l}\text { Open width } \\
\text { by the } \\
\text { branches } \\
(\mathbf{m})\end{array}$ & $\begin{array}{l}\text { Average } \\
\text { surface area } \\
\text { per feet } \\
\left(\mathbf{m}^{2}\right)\end{array}$ & $\begin{array}{l}\text { Total area } \\
\text { impacted } \\
\left(\mathbf{m}^{2}\right)\end{array}$ \\
\hline Bossé & 2 & 16,65 & 37,125 & 41,25 & 15,9 & 655,875 & $\mathbf{1 3 1 1 , 7 5}$ \\
Iroko & 1 & 7,94 & 34,92 & 38,8 & 10 & 388 & $\mathbf{3 8 8}$ \\
Mukulungu & 14 & 322,35 & 41,87 & 43,17 & 25,98 & 1121,532 & $\mathbf{1 5 7 0 1 , 4 5}$ \\
Pau rosa & 2 & 14,68 & 35,5 & 39,45 & 25,4 & 1002,03 & $\mathbf{2 0 0 4 , 0 6}$ \\
Sapelli & 68 & 1332,12 & 39,35 & 43,73 & 22,64 & 990,15192 & $\mathbf{6 7 3 3 0 , 3 3}$ \\
Sipo & 4 & 78,95 & 43,77 & 45,13 & 25,33 & 1142,7906 & $\mathbf{4 5 7 1 , 1 6}$ \\
Tali & 9 & 78,46 & 33,85 & 37,62 & 19,74 & 742,82988 & $\mathbf{6 6 8 5 , 4 7}$ \\
Grand total & $\mathbf{1 0 0}$ & $\mathbf{1 8 5 1 , 1 3 5}$ & $\mathbf{2 6 6 , 3 8 5}$ & $\mathbf{2 8 9 , 1 5}$ & $\mathbf{1 4 4 , 9 9}$ & $\mathbf{8 6 3 , 3 1}$ & $\mathbf{1 3 9 9 8 , 8 8}$ \\
\hline
\end{tabular}

Table 5. Distribution of the forecast areas and actually impacted according to the species cut down.

\begin{tabular}{llllllll}
\hline Species & $\begin{array}{l}\text { Number of } \\
\text { feet felled }\end{array}$ & Total $\left(\mathbf{m}^{\mathbf{3}}\right)$ & $\begin{array}{l}\text { Length of } \\
\text { the tree }(\mathbf{m})\end{array}$ & $\begin{array}{l}\text { Total length } \\
\text { of the tree } \\
(\mathbf{m})\end{array}$ & $\begin{array}{l}\text { Open width } \\
\text { by the } \\
\text { branches } \\
(\mathbf{m})\end{array}$ & $\begin{array}{l}\text { Average } \\
\text { surface area } \\
\text { per foot } \\
\left(\mathbf{m}^{2}\right)\end{array}$ & $\begin{array}{l}\text { Total area } \\
\text { impacted } \\
\left(\mathbf{m}^{2}\right)\end{array}$ \\
\hline Bossé & 2 & 16,65 & 37,13 & 41,25 & 15,9 & 655,88 & $\mathbf{1 3 1 1 , 7 5}$ \\
Iroko & 1 & 7,94 & 34,92 & 38,8 & 10 & 388,00 & $\mathbf{3 8 8}$ \\
Mukulungu & 14 & 322,35 & 41,87 & 43,17 & 25,98 & 1121,53 & $\mathbf{1 5 7 0 1 , 4 5}$ \\
Pau rosa & 2 & 14,68 & 35,50 & 39,45 & 25,4 & 1002,03 & $\mathbf{2 0 0 4 , 0 6}$ \\
Sapelli & 68 & 1332,12 & 39,35 & 43,73 & 22,64 & 990,15 & $\mathbf{6 7 3 3 0 , 3 3}$ \\
Sipo & 4 & 78,95 & 43,77 & 45,13 & 25,33 & 1142,79 & $\mathbf{4 5 7 1 , 1 6}$ \\
Tali & 9 & 78,46 & 33,85 & 37,62 & 19,74 & 742,83 & $\mathbf{6 6 8 5 , 4 7}$ \\
Grand total & $\mathbf{1 0 0}$ & $\mathbf{1 8 5 1 , 1 4}$ & $\mathbf{2 6 6 , 3 9}$ & $\mathbf{2 8 9 , 1 5}$ & $\mathbf{1 4 4 , 9 9}$ & $\mathbf{8 6 3 , 3 1}$ & $\mathbf{1 3 9 9 8 , 8 8}$ \\
\hline
\end{tabular}

Evaluation of the impact to the illumination of the roads indicate to us that the number of feet slaughtered with the road lighting as well as the average surface degraded by essence shows that the Manikara and the Niove, represent the species most slaughtered with the lighting road, followed by the
Test, Tchitola and Paduk. The Pao and the Sapelli, although less represented in the number of feet slaughtered, are the species that cause the most damage to the road lighting because of the importance of their crowns which during the fall cause enormous damage to other stands Table 6. 
Table 6. Distribution of the area impacted by species during the felling of trees during the lighting of forest roads.

\begin{tabular}{lllll}
\hline Species & Number of trees & Area $\left(\mathbf{m}^{\mathbf{2}}\right)$ & Average $\operatorname{area}\left(\mathbf{m}^{\mathbf{2}}\right)$ & Average $\mathbf{a r e a}\left(\mathbf{m}^{\mathbf{2}}\right)$ \\
\hline Ohia & 1 & 313.2 & 313.20 & $3 \%$ \\
Ilomba & 5 & 1894.9 & 378.98 & $4 \%$ \\
Kosipo & 6 & 2294.7 & 382.45 & $4 \%$ \\
Essia & 13 & 5681.19 & 437.01 & $4 \%$ \\
Padouk & 12 & 5854.96 & 487.91 & $4 \%$ \\
Dabema & 4 & 2041.64 & 510.41 & $5 \%$ \\
Manikara & 16 & 8237.26 & 549.89 & $5 \%$ \\
Niové & 16 & 8798.29 & 644.73 & $6 \%$ \\
Tchitola & 13 & 8381.54 & 672.80 & $7 \%$ \\
Ikoro & 1 & 672.8 & 736.89 & $7 \%$ \\
Motombé & 1 & 736.89 & 737.38 & $7 \%$ \\
Tiama & 6 & 4424.29 & 737.38 & $7 \%$ \\
Mukulungu & 1 & 777.63 & 777.63 & $8 \%$ \\
sapelli & 3 & 3638.98 & 1212.99 & $12 \%$ \\
Pao rosa & 2 & 2385.15 & 1492.58 & $15 \%$ \\
Total & $\mathbf{1 0 0}$ & $\mathbf{5 6 7 3 3 . 4 2}$ & $\mathbf{9 8 4 9 . 6 9}$ & $\mathbf{1 0 0 \%}$ \\
\hline
\end{tabular}

We can then see that the feller during the operation of the road lighting performs quite well cuts and sapwood cuts during the controlled feller, which represent respectively $81 \%$ and $60 \%$ of good points. However, efforts remain to be made on the cutting of direction and the cuts of the sapwood which are often carried out occasionally. As for the execution of the security, the feller performs this operation well.

\section{Discussion}

Felling tree defects in developing countries remain a major problem in preserving the forest environment, but also the quality of the tree leaving the forest is generally compromising for future wood processing (Mbete and Oko, 2018). This is why Mbété (2014) believes that the fall of the tree in the tropical forests thus remains among the main causes of destruction of the forest, the branches of the crowns of neighboring trees that break and also cause the formation of windthrow. However, the application of controlled felling nowadays makes it possible to reduce the impact on the forest stand.

Controlled felling is a working technique used to cut a standing tree. It allows to control the fall in order to guarantee a maximum safety for the operator, to avoid the damage to the neighboring trees, to recover a maximum of timber at the base of the tree and to facilitate its extraction. Poorly managed or poorly controlled logging can have several negative impacts on the environment, including:

- amplified damage to the residual stand (broken branches, headless or uprooted trees);

- a financial impact because the damage caused (rolling, cracking, tearing) results in a significant loss of timber;

- endangering operators (Mbété, 2014).

The impact of the fallen tree is measured more in terms of damage to the initial stand than to the ground, even if localized compaction is 
unavoidable. Slaughter indirectly affects all trees of all diameter classes. Smaller classes, however, are more likely to be destroyed while trees of a certain diameter are often only injured (Bertault and Sist, 1995; Durrieu de Madron et al., 1998).

According to several authors who have worked on the operation of the felling of trees: For the first exploitation, when the crowns of trees are very large (up to 30-40 $\mathrm{m}$ in diameter), Garden (1995b) notes for a sampling of 0.35 trees per hectare, that a tree fell to 2.2 stems of commercial species of diameter greater than $20 \mathrm{~cm}$, among the commercial species. The area disturbed by felling reaches $1.6 \%$.

Concerning the remnant stand, Mbolo (1994) for a levy of 0.5 trees per hectare, finds the figures of $6.7 \%$ damaged stems divided into $5.2 \%$ of commercial species, $7.4 \%$ of secondary species. and the rest in complementary species according to the terminology of the Cameroonian national standards, $5.6 \%$ of the area is disturbed.

In the Central African Republic, for an exploitation of 3.7 stems per hectare in semi-deciduous forest, the average surface of gaps due to feller was 350 $\mathrm{m} 2$ per exploited foot, affecting $13 \%$ of the forest area (De Chaterlperron and Commerçon 1986). But the surface of these gaps is very variable: for an Ayous (Triplochiton scleroxylon) with a diameter between 1.3 and $1.4 \mathrm{~m}$, the damage surface on the ground varies from $65 \mathrm{~m} 2$ to $360 \mathrm{~m} 2$. The importance of crown damage depends on the spatial extent of the crowns, but also on the size and density of the surrounding trees that can create cascading damage.

In secondary forest, in Côte d'Ivoire, for mediumsized trees (40 to $50 \mathrm{~cm}$ in diameter, from intermediate stages and with narrow crowns such as Pouo (Funtumia sp.)), The average surface of the gap is about $50 \mathrm{~m} 2$ per tree felled (Sangaré, 1990 quoted by Dupuy, 1998). A study in the Amazon shows that creepers linked each tree to the crowns of three to nine other trees, and that felling creeperrich trees resulted in canopy gaps that were twice as large as those created by falling trees and lianas
(Vidal et al., 1997). Directional felling is also often mentioned in the literature as a way to limit damage.

It allows to introduce the $\log$ to the skidder so as to minimize the maneuvers of the latter (a skidder takes $30 \%$ of his time to place the log in the direction of the skidding track (Mekok, 1995a) and it can also serve occasionally to avoid damage to one or more future stems near the tree to be felled, however, all authors do not agree on its feasibility Bertault and Sist (1995) observe that only 30\% of the trees fall in the expected direction.

Felling rates were estimated by quality for the other important species based on what is practiced in the region and on a study conducted on three species (Bété: Mansonia altissima), (Ayous: Triplochiton scleroxylon), and the (Sapelli: Entandrophragma cylindricum)) (NKié, 1994). However, according to the post-exploitation inventory carried out in the area, quality 1 and 2 trees have not been systematically taken.

According to a study carried out by the A.P.I. project, $20 \%$ of the volume was exploited is abandoned on the forest parks. 12 to $17 \%$ of the abandoned woods are because of the bad technicality of the fellers and the chainsaw (Jardin, 1995a). About $25 \%$ of the felled volume is abandoned on park, all species combined (Forni, 1994). This figure of $25 \%$ corroborates the results of the many researchers (Commett, 1992).

Felling damage is directly related to the number of stems to be harvested per hectare, the size of the felled tree (Sist, 1998). This statement is not confirmed in its entirety by the study conducted by Mirko Méoli (2005). Indeed, in this study, no clear relationship could be found between the size of the tree and the damage caused by the fall of the tree.

In this study, Mirko Méoli, (2005) believes that: <it is possible that other variables such as crown shape and size are significantly involved in the determination of canopy opening >. Similarly, Sist (1998) finds it difficult to significantly limit the 
impact of tree size on the forest stand. In our case, among the species followed, we note that it is the Sipo (useful Entandrophragma) which has the largest average surface compared to the Iroko (Milicia excelsa). As a result, the Sipo (useful Entandrophragma) will open the canopy much more than Iroko.

By this result, we can confirm the hypothesis of Mirko Meoli (2005) because, for $100 \%$ impact caused by the fall of the tree, the crown occupied $90-97 \%$ while the barrel occupies only $3-10 \%$ depending on the type of gasoline. Therefore, to effectively limit the impact of logging on the forest stand, the ideal would be to act, not on the size of the trees, but rather to limit the harvest rate, that is to say the number of trees felled per hectare.

In this regard, to minimize the impact of logging specifically on logging on the environment, the experts (PCI OAB / ITTO, 2005), recommend a harvest rate between 2.5 to 3 feet per hectare.

This sampling rate is higher than that observed in the area of our study: 1 to 2.5 feet per hectare. This result seems to show the scrupulous respect of the Mokabi-Dzanga society in the approach of the EFIR standards established by the international NGOs in the field of environmental management.

The limitation of the maximum number of exploitable stems is directly responsible for the damage on the exploited stand, it proves to be an effective measure for the reduction of the damages and the durability of the development (Dupuy, 1998). The Dimako Integrated Development and Production (API) project proposed the following maxima for the exploitation: three trees harvested per hectare, $40 \mathrm{~m} 3$ / ha and a minimum distance between each exploited foot of $40 \mathrm{~m}$ ( Durrieu de Madron et al., 1998b).

On the application of the controlled feller technique:

Our study on the application of controlled feller concerned two specific aspects, that of feller at the level of production (felling of trees exploited) and road lighting. Our observations on the two components were made on samples of 100 feet per axis. At the end of this work, it appears that the application of the controlled slaughtering technique is not applied rigorously for all the slaughterers according to the steps of the cutting of the tree (notch of direction and hinge of wood remaining). In addition, there is poor execution of the following steps for the A3 and A4 slaughterers: cutting, sapwood cutting and safety (retaining tab). It is the same for the road lighting feller who does not apply at all the cutting of the hinge of wood on the trees other than those exploited and less rigorous on the application of all the other stages.

According to Kalambayi Wa Kabongo (2007), the norms of controlled feller essentially boil down to the correct application of the stripping, the cutting of direction and a correct cut forming a good hinge of wood, a low level of the cuts and competent staff. This statement is corollary to that given by (FAO, 2003) in the regional code of low impact logging in the humid tropical rain forests of Central and West Africa.

These assertions show us how important it is to apply not just controlled feller, but to do so by following all of these steps and in order of importance, the management notch and the wood retent hinge. It is all the more important because it guarantees maximum operator safety, avoids damage to future stems and regeneration on the ground, uses as much volume as possible from the felled tree and facilitates as much as possible a favorable position of the balls in future operations. Despite the fact that certain stages of the execution of controlled feller are observed by the slaughterers, it is thought that particular attention must be paid to the scrupulous respect of the other steps, in our opinion the most important ones on the orientation of the tree to be felled and for the safety of the operator, namely the direction of fall and the constitution of the hinge for both production fellers and road lighting.

The damage caused to the felling of production 
differs from that of road lighting for the following reasons:

$\checkmark$ At the level of production, the damage is enormous because the felling is done in a closed forest where one finds a large population of the stems of future. At the fall of the tree, it leads to other trees connected by creepers dead trees, causing significant damage to the existing forest stand. This damage is caused for the most part by the crown of fallen trees;

$\checkmark$ As for the felling of road lighting, the damage is less important. At this level lighting is often done by felling smalldiameter trees that often fall on the roads.

These statements confirm the study by (Mbete, 2014) on the "Assessment of the Impact of Logging Operations on Vegetation and Wildlife in Mokabi" which concluded that the damage caused by the crown is in the order of $90-97 \%$, while the damage caused by the is only about $3-10 \%$.

This is why the rigorous application of controlled felling seems for us, a practical solution to avoid the damage on the stand by the fact that it gives the possibility to the operator of:

$\checkmark$ divert the direction of the tree at an angle of $30^{\circ}$ to either side of the natural direction of the tree, to avoid large trees, future stems and other obstacles;

$\checkmark$ proceed to the slaughtering before feller, in order to avoid the trees connected by lianas being trained at the time of the fall of the tree;

In general, we think about the training and qualification of the fellers in order to solve the thorny problem of the directional felling in tropical dense forest.

\section{Conclusion}

In order to practice reduced impact logging, in the operation of controlled logging, we think through the logging activities, a process that meets the requirements of responsible management through a development of sustainable forestry.

The Congo has opted for the sustainable management of its forest ecosystem, through the development of forest concessions with the consequence of the application of the measures of a low impact logging (EFIR). Among these measures are in good application of this technique in all these steps is necessary, among which the appreciation of the direction of fall, the notch direction well oriented.

The forecast production never fits with the actual production, which could perhaps be explained by the complicity of the forest operations on the ground: the topography of the soil, the plant formations by their composition of the undergrowth, the material and the methods of work. Export production significantly exceeds national production, which is explained by the shortage of sawn timber at the national level due to the demand for high-value species by the international market. The areas impacted depended on the species to be felled, but also on the method chosen by the faller. As for the quality of the felling, it is suggested that logging companies periodically train fellers on the application of the controlled felling technique.

\section{Conflict of interest statement}

Authors declare that they have no conflict of interest.

\section{References}

Boundzanga, G. C., 2005. Evaluation des ressources forestières mondiales Congo. Rapport national FAO. 68 p.

Bertault, J. G., Sist, P., 1995. Impact de l'exploitation forestière en forêt naturelle. Bois et Forêts des Tropiques. 245, 5-21.

Commett., 1992. Etude sur le système d'attribution et de suivi des titres d'exploitation forestière pour le bois d'œuvre. Tome 2 - Analyse critique et propositions. Draft MINEF/Banque Mondiale. 27p. 
Durrieu de Madron L., Forni E., Karsenty, A., Loffeier, E., Pierre, J. M., 1998b. Le projet d'aménagement Pilote intégré de Dimako (Cameroun) (1992-1996). Projet FORAFRI, $160 \mathrm{p}$.

Dupuy, B., 1998. Bases pour une sylviculture en forêt dense tropicale humide africaine. Projet FORAFRI, $328 \mathrm{p}$.

De Chatelperron, G., Commerçon, R., 1986. Mise en exploitation du dispositif de recherche en forêt naturelle dans les forêts de Boukoko et La Lolé en République Centrafricaine Projet F.A.C. A.R.R.F. C.T.F.T., 58 p.

FAO, 2003. Code Régional d'exploitation forestière à faible impact dans les forêts denses tropicales humides d'Afrique Centrale et de l'Ouest $152 \mathrm{p}$.

Forni, E., 1994. Etude de l'exploitation - Bilan de l'exploitation de la Vente de Coupe 1112. Rapport technique A.P.I.Dimako, 12 p.

Jardin, J.L., 1995a. Etude de l'abandon des bois sur les parcs d'exploitation en forêt. Rapport technique A.P.I. Dimako, 15 p.

Jardin, J. L., 1995b. Etude des dégâts d'exploitation en forêt sempervirente. API Dimako, Cameroun. CIRAD / ONF. 10 p.

Kalambayi wa Kabongo, A. L., 2007. Guide opérationnel des normes d'exploitation forestière à Impact réduit (EFIR) $11 \mathrm{p}$.

Mbete, P., 2014. Evaluation de l'incidence des opérations de l'exploitation forestière sur la végétation et la faune dans l'Unit2 Forestière d'Aménagement de mokabi-dzanga. Thèse de doctorat unique, Université Marien Ngouabi : Faculté des Sciences et Techniques. 217p

Mbete, P., Oko, C. S., 2018. Évaluation de l'abattage contrôlé et estimation des pertes de bois en grume dans l'Unité Forestière d'Aménagement Loundoungou-Toukoulaka au Nord Congo. J. Appl. Biosci. 123, 1231912331.
M'bolo Bamela, D., 1994. Etude des dégâts d'exploitation dans la zone d'action du projet aménagement pilote intégré (API) de Dimako. Mémoire ENSA, Université de Dschang, Cameroun. 79 p.

Mekok, M., 1995a. Etude des prix de revient du m3 de bois au départ du chantier d'exploitation forestière et de l'incidence de la planification des pistes de débardage sur la pratique actuelle de l'exploitation. Rapport technique A.P.I. Dimako. 49 p.

Mirko, M., 2005. Impact de l'exploitation sur l'écosystème forestier dans les concessions de la Congolaise Industrielle des Bois (CIB) 79 p.

Nkié, M., 1994. Estimation des coefficients de commercialisation de trois essences forestières (Ayous, Bété et Sapelli) dans la zone forestière de Dimako: cas de la SFID. Mémoire de fin d'étude de l'université de Dschang, $71 \mathrm{p}$.

PCI OAB-OIBT, 2005. Gestion durable des forêts tropicales naturelles d'Afrique. Série Développement de politiques. $72 \mathrm{p}$.

UICN, 1991. - Ecosystèmes forestiers d'Afrique Centrale. 321p.

Sangaré, M., 1990. Contribution à l'établissement du plan de gestion du massif forestier de YapoAbbé. SODEFOR - Côte d'Ivoire, 106 p.

Sist, P., Dykstra, D., Fimbel, R., 1998. Reduced impact logging guidelines for lowland and hill dipterocarp forest in Indonesia. CIFOR occasional paper $\mathrm{n}^{\circ}$ 15.Directives pour l'application des techniques d'exploitation à faible impact (EFI) au Gabon: objectifs, principaux et enjeux. Séminaire FORAFRI de Libreville- Session 4: exploitation, aménagement, gestion, 26p.

Vidal, E., Johns, J., Gerwing, J.J., Barreto, P., Uhl, C., 1997. Vine management for reduced impact logging in eastern Amazonia. For. Ecol. Manage. 98, 105-114.

\section{How to cite this article:}

Mbete, P., Ayessa, L., Oko, C. S., 2018. Evaluation of the controlled felling and estimation of the areas impacted by the timber harvesting operation at the Ngoua II Forest Exploitation Unit (UFE) in Southern Congo. Int. J. Curr. Res. Biosci. Plant Biol. 5(8), 40-51.

doi: https://doi.org/10.20546/ijcrbp.2018.508.006 